\title{
Educational Use of Animals in Europe Indicates Reluctance to Implement Alternatives
}

\author{
Miriam A. Zemanova1, Andrew Knight ${ }^{2}$ and Susanna Lybcek ${ }^{3}$ \\ ${ }^{1}$ Animalfree Research, Bern, Switzerland; ${ }^{2}$ Centre for Animal Welfare, University of Winchester, Winchester, UK; ${ }^{3}$ The Norwegian Animal Protection \\ Alliance (Dyrevernalliansen), Oslo, Norway
}

\begin{abstract}
Animals have been considered an indispensable tool to teach about the functioning of living organisms, to obtain skills necessary for practicing human and veterinary medicine, as well as for acquiring skills for caring for and conducting experiments on animals in laboratories. However, the efficacy of this practice has been questioned in recent decades, and societal views have evolved to place a much stronger emphasis on animal welfare and ethics that needs to be reflected in our teaching and training practices. Currently, many alternatives to harmful animal use are available, and it is not clear why thousands of animals continue to be used every year for educational and training purposes. Therefore, this study aimed to identify reasons for the lack of uptake of non-harmful educational and training methods by analyzing recently published non-technical summaries in the EU and EEA Member States and to provide examples of alternatives for specific learning objectives. Results from non-technical summaries from 18 countries spanning the most recent years (2017-2019) revealed that the two main perceived reasons for continued animal use are: 1) the necessity to use a living animal for "proper" learning and 2) the lack of an adequate alternative. We argue that these reasons often do not reflect reality. In conclusion, we consider it is necessary to place a stronger emphasis on engagement with ethical questions that underlie the use of animals and careful consideration of how the learning objectives could be achieved through nonharmful alternatives.
\end{abstract}

\section{Introduction}

Animals have been used as anatomy learning tools by artists and scientists for millennia (Hart et al., 2008). Physicians and philosophers in ancient Greece and Rome conducted experiments on live animals to understand animal anatomy, and another upsurge of experimentation on animals occurred during the Renaissance (Bishop and Nolen, 2001). Even today, harmful use of animals remains an integral part of education and training in high schools, universities and the military across the globe (Balls, 2018; Rubeis and Steger, 2018). Animals are killed for use in anatomy dissections and subjected to invasive experiments to demonstrate scientific principles within disciplines such as physiology, biochemistry and pharmacology. They are used also as clinical and surgical skills training models. For instance, pigs are still commonly used in terminal experiments to practice surgical skills in human medicine (Deonarain et al., 2020; Giménez et al., 2020), and rabbits are used for training neonatal intubation procedures (Okhovat et al., 2020; Ulmer et al., 2020).

It has been estimated that in any country, $1-10 \%$ of animals used in experiments are used for education and training (Akbarsha et al., 2013). Within EU and EEA Member States, thousands of animals are used for educational and training purposes every year (Tab. 1). However, only animals protected by the EU Directive 2010/63 (i.e., vertebrates and cephalopods) are included in the EU and EEA Member States' national statistical reports (EC, 2020). Moreover, not included in the reports are animals that are bred (potentially for other purposes), killed, and their cadavers then used in educational procedures. The actual number of animals used in education and training is therefore likely to be higher. And yet, the use of animals in education has been criticized by both students (Akbarsha, 2007; Oakley, 2013) and educators (Waldau, 2007; Hansen, 2014; Tolbert, 2019). In veterinary education, in particular, any harmful use of animals directly contradicts the commitment of veterinarians to "first, do no harm".
Received November 11, 2020; Accepted March 30, 2021; Epub April 6, 2021; ( ) The Authors, 2021.

ALTEX 38(3), 490-506. doi:10.14573/altex.2011111

Correspondence: Miriam A. Zemanova (PhD)

Animalfree Research

Postgasse 15, 3011 Bern, Switzerland

(miriam.andela.zemanova@gmail.com)
This is an Open Access article distributed under the terms of the Creative Commons Attribution 4.0 International license (http://creativecommons.org/licenses/by/4.0/) which permits unrestricted use, distribution and reproduction in any medium, provided the original work is appropriately cited. 
Tab. 1: Number of animals used for educational and training purposes in the EU and EEA Member States in 2014-2018, according to the national statistical reports

Liechtenstein banned all animal experiments and educational animal use in 1989. Source: European Commission website ${ }^{a}$ and personal communication with the Norwegian Food Safety Authority.

\begin{tabular}{|c|c|c|c|c|c|}
\hline Country & 2014 & 2015 & 2016 & 2017 & 2018 \\
\hline Austria & 3,188 & 1,925 & 2,657 & 3,108 & 2,889 \\
\hline Belgium & 15,178 & 8,539 & 8,882 & 8,051 & 7,442 \\
\hline Bulgaria & $\begin{array}{l}\text { Category not } \\
\text { reported }\end{array}$ & $\begin{array}{l}\text { Category not } \\
\text { reported }\end{array}$ & $\begin{array}{l}\text { Category not } \\
\text { reported }\end{array}$ & $\begin{array}{l}\text { Category not } \\
\text { reported }\end{array}$ & $\begin{array}{l}\text { Category not } \\
\text { reported }\end{array}$ \\
\hline Croatia & 1,188 & 1,217 & 1,203 & 1,428 & 1,321 \\
\hline Cyprus & Not found & Not found & Not found & Not found & Not found \\
\hline Czech Republic & 7,474 & 15,673 & 16,143 & 7,873 & 9,172 \\
\hline Denmark & 5,745 & 6,151 & 5,387 & 4,463 & 5,132 \\
\hline Estonia & $\begin{array}{l}\text { Category not } \\
\text { reported }\end{array}$ & $\begin{array}{l}\text { Category not } \\
\text { reported }\end{array}$ & $\begin{array}{l}\text { Category not } \\
\text { reported }\end{array}$ & 38 & 38 \\
\hline Finland & 1,738 & 1,170 & 1,753 & 1,606 & 2,153 \\
\hline France & 25,908 & 28,271 & 34,280 & 35,512 & 41,510 \\
\hline Germany & 56,235 & 55,893 & 48,941 & 53,121 & 55,386 \\
\hline Greece & 1,467 & 1,017 & 637 & 1,119 & 923 \\
\hline Hungary & 5,159 & 1,968 & 2,688 & 2,370 & 2,030 \\
\hline Iceland & Not found & Not found & Not found & Not found & Not found \\
\hline Ireland & 155 & 389 & 250 & 274 & 343 \\
\hline Italy & 1,140 & 1,042 & 1,787 & 1,598 & Not yet available \\
\hline Latvia & 150 & 150 & 40 & 22 & 24 \\
\hline Liechtenstein & Not applicable & Not applicable & Not applicable & Not applicable & Not applicable \\
\hline Lithuania & 98 & 44 & 101 & 606 & 1,382 \\
\hline Luxembourg & 0 & 0 & 0 & 144 & 171 \\
\hline Malta & 0 & 0 & 0 & 0 & Not found \\
\hline Netherlands & 18,240 & 19,628 & 14,714 & 22,074 & 14,801 \\
\hline Norway & 1,065 & 535 & 1,097 & 713 & 1,027 \\
\hline Poland & 4,688 & 2,688 & 1,597 & 1,129 & 1,117 \\
\hline Portugal & 254 & 3 & 102 & 392 & 228 \\
\hline Romania & 2,013 & 7,498 & 1,572 & 1,239 & Not yet available \\
\hline Slovakia & 0 & 8 & 0 & 56 & 30 \\
\hline Slovenia & 163 & 118 & 53 & 122 & 106 \\
\hline Spain & 11,149 & 13,994 & 12,261 & 11,785 & 10,021 \\
\hline Sweden & 1,409 & 3,331 & 5,155 & 4,248 & 4,958 \\
\hline UK & 1,814 & 1,845 & 1,438 & 1,235 & 1,327 \\
\hline TOTAL & 148,176 & 172,044 & 131,886 & 162,193 & 124,345 \\
\hline Countries with missing data & 5 & 5 & 5 & 5 & 7 \\
\hline
\end{tabular}

a https://ec.europa.eu/environment/chemicals/lab_animals/member_states_stats_reports_en.htm 
Moreover, since the implementation of the 3Rs principles (Russell and Burch, 1959) into animal welfare legislation and policy worldwide, the use of animals should be avoided whenever possible (the replacement principle).

Fortunately, there are training methods available that can provide comparable or even better learning outcomes than the use of animals. A broad array of alternatives exists, which has been described in detail elsewhere (Knight, 2007; Zemanova and Knight, 2021). Alternatives include the use of ethically-sourced animal or human cadavers, computer simulations, videos, anatomical models, clinical and surgical skills models, full-body high-fidelity model-driven simulators, virtual reality simulators, non-invasive experimentation on oneself or one's classmates, clinical and surgical rotations, and more. These educational tools usually help overcome educational and training limitations of the more traditional methods (Al-Elq, 2010). They can provide the opportunity to train a wide variety of personnel in technical and non-technical skills without causing harm to animals or real patients. Furthermore, trainees have the possibility to train rare and life-threatening events as many times as necessary (repetitive practice) in a short time. This provides the opportunity to follow controlled training programs, with levels of difficulty adjusted to previous experience, leading to more efficient training (Crofts et al., 2006; Draycott et al., 2006; Guedes et al., 2019). Some simulators and simulation environments provide the possibility to assess performance and debrief after a simulation exercise, based on objective or subjective data. Such features can enhance educational feedback beyond what is generally possible in clinical or scientific practices or when using animals as training subjects (Salas et al., 2009; Grant et al., 2010).

Moreover, the development of non-animal models and animal-free simulation environments for education, training and research is now a stand-alone methodology of similar value to laboratory experiments and clinical trials (Hardman and Ross, 2006; Pawlowski et al., 2018; Labrague et al., 2019). Besides the use of available non-animal methods, new educational and training needs can be met by good curricular design and implementation of potentially new media (Jukes, 2004; Coombs et al., 2017; Pawlowski et al., 2018).

However, the number of animals used for educational and training purposes has remained stable over recent years (Tab. 1), which suggests that such an educational strategy is not yet implemented as standard throughout the EU and EEA Member States and that there may be factors hindering the adoption of non-harmful education and training methods. As a part of the EU Directive 2010/63 on the protection of animals used for scientific purposes, every Member State is required to publish anonymized non-technical summaries (NTSs) of projects using live animals for scientific purposes. A project is defined by the EU Directive 2010/63 as "a programme of work having a defined scientific objective and involving one or more procedures", and a procedure means "any use, invasive or non-invasive, of an animal for experimental or other scientific purposes, with known or unknown outcome, or educational purposes, which may cause the animal a level of pain, suffering, distress or lasting harm equivalent to, or higher than, that caused by the introduction of a needle in accordance with good veterinary practice". It is also important to note that experiments that do not affect the physical integrity of the animal can lead to significant distress. For instance, the forced swim test with exhaustion as the end-point - a behavioral experiment used in psychiatric research - has been classified as "severe" (EC, 2009; Strittmatter, 2017).

The requirement for publishing NTSs came into effect for projects authorized after January 1, 2013, except for those authorized under a simplified administrative procedure (Article 42). Each NTS must include information on objectives, predicted harms and benefits, number and species of animals to be used, and a demonstration of adherence to the 3Rs principles (EC, 2013). Therefore, NTSs can provide specific information on what efforts are being made to implement the 3Rs and what obstacles remain for achieving education without harming animals.

The aims of this study were: 1) to elucidate the reasons for continued use of animals for educational and training purposes within the EU and EEA Member States by analyzing recently published NTSs, and 2) to provide an overview of available alternatives for the identified procedures on animals for educational or training purposes.

\section{Methods}

\section{Search for and analysis of non-technical summaries}

First, we searched for the NTSs on the dedicated EU and EEA Member State websites, primarily using the links provided by the EU Commission ${ }^{1}$, supplemented with our own search efforts. We only evaluated the NTSs of projects whose sole purpose for using animals was teaching and training. Consequently, the NTSs identified as research projects of $\mathrm{PhD}$ or MSc students were not included, as the primary purpose of these projects is basic or applied research, and education is a secondary purpose (Fig. 1). We conducted this survey from October 2019 until May 2020. We decided to assess the most recent years, i.e., 2017-2019, extracting data about the type of procedure on an animal for educational or training purposes, species used, and compliance with the $3 \mathrm{Rs}$ principles. In the section on the 3 Rs principles, we recorded the reason(s) given to justify the use of animals, i.e., why they could not be replaced. To maintain consistency, the first author assessed all reports.

\section{Review of available educational alternatives}

Second, since we suspected that one of the reasons given for continued animal use for teaching and training purposes would be that there are no suitable animal-free models available, we conducted a literature search to identify any alternatives that may already exist for each of the types of procedures on animals for educational or training purposes identified in the

\footnotetext{
1 http://ec.europa.eu/environment/chemicals/lab_animals/nts_en.htm
} 


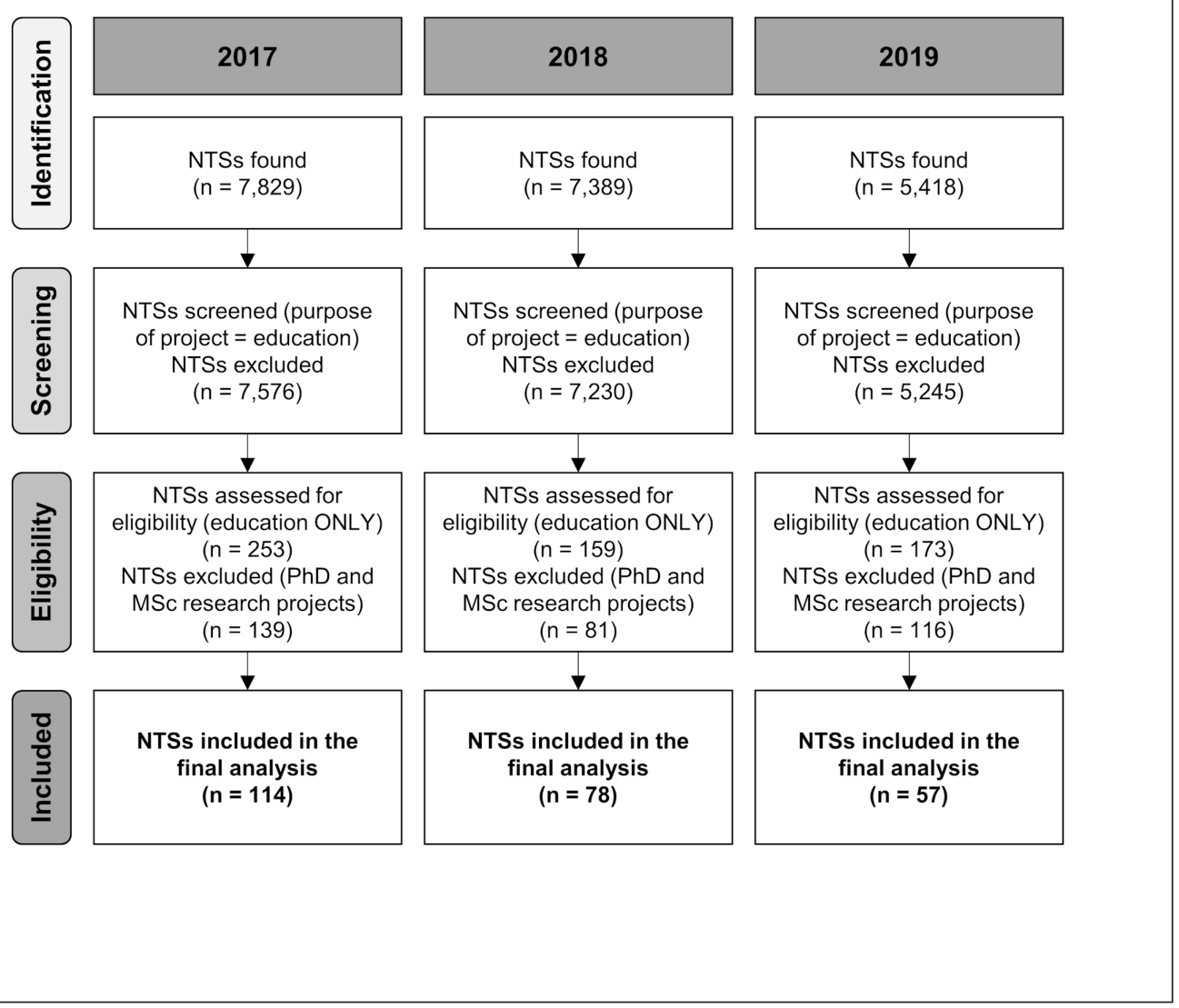

Fig. 1: Steps undertaken during the search for eligible non-technical summaries (NTSs) following the PRISMA guidelines for systematic reviews (Moher et al., 2009) The number of NTSs (n) that were identified, screened, retained or excluded are shown at each stage.

Tab. 2: Key databases that contain information on alternatives in education

\begin{tabular}{|l|l|l|}
\hline Name & Description & Website \\
\hline $\begin{array}{l}\text { InterNICHE } \\
\text { Database }\end{array}$ & $\begin{array}{l}\text { InterNICHE is the International Network for Humane Education. The network } \\
\text { focuses on animal use and alternatives within biological science, medical and } \\
\text { veterinary medical education. }\end{array}$ & $\begin{array}{l}\text { http://www.interniche.org/ } \\
\text { en/alternatives }\end{array}$ \\
\hline NORINA & $\begin{array}{l}\text { An English-language database containing information on approximately } \\
\text { 3,000 audiovisual aids that may be used as alternatives or supplements to the use of } \\
\text { animals in education and training, including dissection alternatives, at all levels from } \\
\text { junior school to university. The information in the database has been collected from } \\
1991 \text { onwards. }\end{array}$ & $\begin{array}{l}\text { https://norecopa.no/norina- } \\
\text { database }\end{array}$ \\
\hline Science Bank & $\begin{array}{l}\text { Project of Animalearn (http://www.animalearn.org). Science Bank is a free lending } \\
\text { library of humane science products in the US. Links to online resources are also listed. }\end{array}$ & https://thesciencebank.org/ \\
\hline
\end{tabular}

NTSs. We used search strings containing the type of procedures on animals and the words "alternative", "simulator" or "model" within the Google Scholar bibliographic database. This was chosen for its speed of use, accepting that search results would not be comprehensive and not replicable. Additionally, we consulted several databases of alternative methods for education and training (Tab. 2).

\section{Results}

\subsection{Published non-technical summaries}

Liechtenstein banned scientific and educational animal use in 1989 (Kuhse and Singer, 1998). No NTSs could be found for Greece, Malta and Iceland. Croatia, Cyprus, Hungary and Sweden only had NTSs available for the period before 2017. 
Tab. 3: Number of identified and analyzed non-technical summaries (NTSs) of projects in which animals were used for educational or training purposes in the 31 EU and EEA Member States in 2017-2019

Liechtenstein banned all animal experiments and educational animal use in 1989.

\begin{tabular}{|c|c|c|c|c|}
\hline Country & 2017 & 2018 & 2019 & TOTAL \\
\hline Austria & 16 & 20 & 8 & 44 \\
\hline Belgium & 4 & 1 & NTSs not yet available & 5 \\
\hline Bulgaria & 0 & NTSs not yet available & NTSs not yet available & 0 \\
\hline Croatia & NTSs not yet available & NTSs not yet available & NTSs not yet available & 0 \\
\hline Cyprus & NTSs not yet available & NTSs not yet available & NTSs not yet available & 0 \\
\hline Czech Republic & 16 & 7 & 23 & 46 \\
\hline Denmark & NTSs not searchable & NTSs not searchable & NTSs not searchable & 0 \\
\hline Estonia & 2 & 2 & 2 & 6 \\
\hline Finland & 7 & 5 & 2 & 14 \\
\hline France & 11 & NTSs not yet available & NTSs not yet available & 11 \\
\hline Germany & 2 & 2 & 3 & 7 \\
\hline Greece & NTSs not found & NTSs not found & NTSs not found & 0 \\
\hline Hungary & NTSs not yet available & NTSs not yet available & NTSs not yet available & 0 \\
\hline Iceland & NTSs not found & NTSs not found & NTSs not found & 0 \\
\hline Ireland & 2 & 2 & 0 & 4 \\
\hline Italy & NTSs not yet available & 0 & NTSs not yet available & 0 \\
\hline Latvia & 0 & 0 & 1 & 1 \\
\hline Liechtenstein & Not applicable & Not applicable & Not applicable & 0 \\
\hline Lithuania & 2 & 0 & NTSs not yet available & 2 \\
\hline Luxembourg & 0 & 0 & 1 & 1 \\
\hline Malta & NTSs not found & NTSs not found & NTSs not found & 0 \\
\hline Netherlands & 32 & 9 & 0 & 41 \\
\hline Norway & 5 & 9 & 10 & 24 \\
\hline Poland & 11 & 17 & 5 & 33 \\
\hline Portugal & 0 & 0 & 1 & 1 \\
\hline Romania & NTSs not searchable & NTSs not searchable & NTSs not searchable & 0 \\
\hline Slovakia & 2 & 1 & 1 & 4 \\
\hline Slovenia & 0 & 1 & 0 & 1 \\
\hline Spain & NTSs without dates & NTSs without dates & NTSs without dates & 0 \\
\hline Sweden & NTSs not yet available & NTSs not yet available & NTSs not yet available & 0 \\
\hline UK & 2 & 2 & NTSs not yet available & 4 \\
\hline TOTAL & 114 & 78 & 57 & 249 \\
\hline
\end{tabular}

The NTSs from Denmark, Romania and Spain were excluded from the analyses due to a format preventing search or due to missing dates. The NTSs from some of the target years have not yet been published by several countries (Tab. 3). In total, for the period 2017-2019, we were able to identify and analyze 249 NTSs purely focused on education and training from 18 out of 31 EU and EEA Member States (Tab. 3; Fig. 1).

\subsection{Type of procedures on animals for educational or training purposes, animal species, and justification for using animals}

We identified six general types of procedures on animals associated with educational animal use (Tab. 4; Fig. 2A). Animals were used in 1) behavioral experiments (6 NTSs), 2) experiments in physiology (40 NTSs), 3) insemination and pregnancy diagnosis 


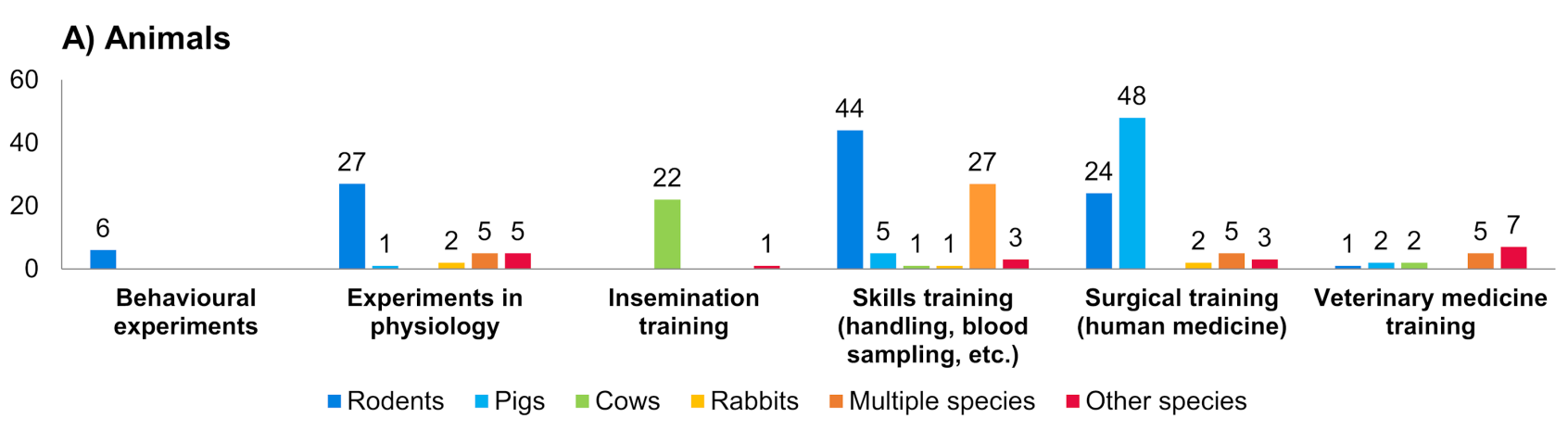

B) Reasons

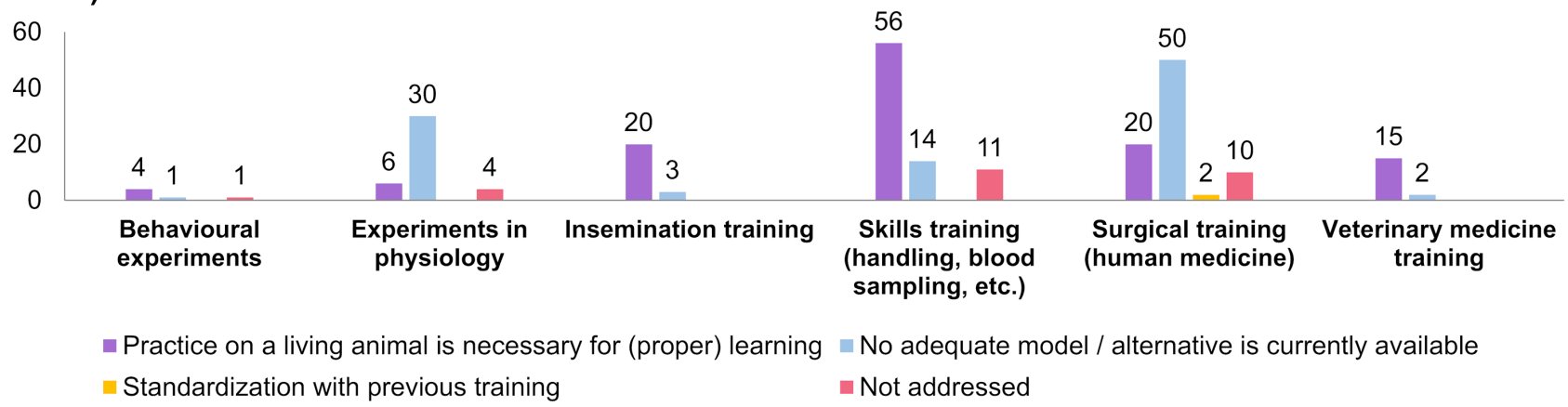

Fig. 2: Results of the analysis of 249 non-technical summaries of animal use for educational and training purposes across 18 EU and EEA Member States in 2017-2019

A) Animal species used for different types of procedures for educational or training purposes (category "Other" includes birds, cats, crustaceans, dogs, foxes, fish, frogs, horses and sheep). B) Reasons reported for why procedures could not be replaced. Please note that the animal procedure type "Skills training" covers primarily laboratory animal courses but might also include NTSs of veterinary medicine training in cases where the exact category was not clear.

training (23 NTSs), 4) skills training (e.g., handling, blood sampling, injection of medications, bronchoscopy training, the practice of euthanasia, 81 NTSs), 5) surgical training in human medicine (82 NTSs) and 6) veterinary medicine training (17 NTSs). The most commonly used species across the types of procedures on animals for educational or training purposes were rodents (102 NTSs), except for insemination training and surgical skills, where cows (23 NTSs) and pigs (48 NTSs), respectively, were used most often.

Among the analyzed NTSs, three main reasons were given for animal use (and not replacing the animal with an alternative): 1) practice on a living animal was deemed necessary for "proper" learning (e.g., because the handling of animals is part of the learning process; 121 NTSs), 2) there was a requirement to use the same approach as in previous trainings to ensure standardization with past teaching ( 2 NTSs), and 3) no model or alternative currently available was considered adequate (e.g., due to complexity of emergency surgeries; 100 NTSs). Rather surprisingly, 26 NTSs did not include any justification for why replacement was not possible (Fig. 2B). In the follow- ing subsections, we list several examples of the analyzed NTSs (Tab. 4), describing how animals were used as well as corresponding available alternatives.

\subsection{Examples of available alternatives for the identified types of procedures on animals for educational or training purposes}

Our literature search revealed the existence of multiple alternatives for the types of procedures on animals for educational or training purposes identified in the NTSs. Here, we provide only a limited number of examples (Tab. 5) using the same categories used in Table 4 and Figure 2.

\subsubsection{Behavioral experiments}

Animal behavior can be demonstrated through video documentation (Tab. 5, lines 1-2) of previously conducted experiments (see the examples in Tab. 4, lines 1-2). Other alternatives to using animals in behavioral experiments, in general, are non-harmful interaction with domesticated species, observational studies of sanctuary animals, and field (observational) studies of free-liv- 
Tab. 4: Examples of procedures on animals for educational or training purposes reported in the non-technical summaries

\begin{tabular}{|c|c|c|}
\hline Line no. & Species & Description of the procedure in the NTS \\
\hline \multicolumn{3}{|c|}{ Behavioral experiments } \\
\hline 1 & Rodents & $\begin{array}{l}\text { "The aim of the project is to present selected behavioural procedures to students during internships. } \\
\text { For this purpose, mild behavioural procedures were selected, presenting an overview of the techniques } \\
\text { used to study compounds with antidepressant, anxiolytic and antipsychotic potential. Therefore, a } \\
\text { presentation of the most commonly used screening tests such as: SIH, Porsolt test, elevated cross-maze } \\
\text { test, tail suspension test, social interactions, and new object recognition tests are planned. The animals } \\
\text { will be divided into } 2 \text { groups: control and reference group receiving an active dose of a compound with } \\
\text { antidepressant (Imipramine) or anxiolytic (Diazepam) or psychotic (MK-801) potential. The overall goal of } \\
\text { the project is to present students with 'model' behavioural responses so that they can recognize the } \\
\text { characteristic behaviour in animals and interpret it correctly." }\end{array}$ \\
\hline 2 & Rodents & $\begin{array}{l}\text { "In addition to the practical work carried out on anesthetized and analgesic animals, students are } \\
\text { introduced to behavioural study using various tests carried out in mice. These tests are tools used } \\
\text { routinely in the modelling of human pathologies to assess motor, sensory, memory deficits, and test the } \\
\text { effectiveness of pharmacological treatments. Students perform five different tests: three motor tests } \\
\text { (prehensile traction test, pole test, and footprint test), a memory test (spontaneous alternation), and a } \\
\text { resignation test (forced swim test)." }\end{array}$ \\
\hline \multicolumn{3}{|c|}{ Physiology experiments } \\
\hline 3 & Rodents & $\begin{array}{l}\text { "The animal testing labs on rats and mice offered will prepare all students for the acquisition of skills in } \\
\text { experimental pharmacology and for understanding the mechanisms of action of drug molecules used in } \\
\text { human and veterinary therapy." }\end{array}$ \\
\hline 4 & Frogs & $\begin{array}{l}\text { "The teaching unit allows students to record in vivo the nervous and muscular electrical activities under } \\
\text { different experimental conditions. The experiment is done on the sciatic nerve and the gastrocnemius } \\
\text { muscle of the frog." }\end{array}$ \\
\hline 5 & Crustaceans & $\begin{array}{l}\text { "Field course for students in zoophysiology, } 3^{\text {rd }} \text {-year bachelor. Students will learn how some animals in } \\
\text { seawater can live with altered ionic concentration and osmolarity in extracellular fluid when exposed to } \\
\text { different salt content. A sample of the extracellular fluid of beach crab in seawater and a sample from a } \\
\text { crab after stay in brackish water will be taken." }\end{array}$ \\
\hline \multicolumn{3}{|c|}{ Insemination and pregnancy diagnosis training } \\
\hline 6 & Cows & "Preparatory training for the part of the degree in the insemination of farm animals (cattle)." \\
\hline \multicolumn{3}{|c|}{ Skills training } \\
\hline 7 & Rodents & $\begin{array}{l}\text { "The purpose of this project is to train researchers in a variety of basic procedures that are commonly } \\
\text { required within research projects. This is necessary so that the researchers can perform these procedures } \\
\text { in a competent manner that minimises distress to the animals." }\end{array}$ \\
\hline 8 & Rodents & $\begin{array}{l}\text { "The aim of this project is to train employees in several biotechnical actions on laboratory animals - mainly } \\
\text { standard and some more complex - in the context of building and maintaining animal care and } \\
\text { biotechnical skills. Animals will eventually be killed according to legally prescribed methods. The killing can } \\
\text { also be part of the training." }\end{array}$ \\
\hline \multicolumn{3}{|c|}{ Surgical training (human medicine) } \\
\hline 9 & Pigs & $\begin{array}{l}\text { "The course aims to train surgeons in minimally invasive surgical techniques. Student surgeons perform } \\
\text { various routine operations on anesthetized pigs in order to learn the appropriate skills for interventions on } \\
\text { human patients." }\end{array}$ \\
\hline 10 & Rodents & $\begin{array}{l}\text { "This course (Practical Training Course in Microvascular Surgery) has the sole aim and objective of } \\
\text { providing suitably skilled surgeons with the highest quality instruction and technical training to allow them } \\
\text { to undertake (or support) microvascular surgery on patients in their clinical practice." }\end{array}$ \\
\hline \multicolumn{3}{|c|}{ Veterinary medical training } \\
\hline 11 & $\begin{array}{l}\text { Rats and } \\
\text { rabbits }\end{array}$ & $\begin{array}{l}\text { "Before the actual experiment / manipulation and examination of small mammals (rabbits, rats), } \\
\text { the correct examination and other techniques will be presented so that the actual clinical examination and } \\
\text { other interventions take place according to the law. For blood collection, intravenous catheter insertion, } \\
\text { and urethral catheterization, all animals will be placed under general and analgesics (medetomidine, } \\
\text { ketamine, butorphanol) will be administered so that they do not feel pain or fear. Furthermore, endoscopy }\end{array}$ \\
\hline
\end{tabular}




\begin{tabular}{|l|l|l|}
\hline \multicolumn{2}{|l|}{ Veterinary medical training } \\
\hline & $\begin{array}{l}\text { of the oral cavity, endoscopic examination of the external auditory canal, and vaginoscopy, which are } \\
\text { non-invasive or minimally invasive procedures, will be performed. Before laparotomy (access to the } \\
\text { abdominal cavity and procedures in the oral cavity), an overdose of anesthetic will be performed and the } \\
\text { experimental animal will not regain consciousness. Further surgical procedures will therefore take place } \\
\text { on the carcasses." }\end{array}$ \\
\hline 12 & $\begin{array}{l}\text { "Teaching and assessing clinical skills of undergraduate veterinary students using cattle. The objective is to } \\
\text { teach undergraduate veterinary students various techniques including: 1) how to perform epidural } \\
\text { anaesthesia (spinal block) and urinary catheterisation, 2) how to administer injections by various routes, } \\
\text { 3) how synchronisation of the oestrous cycle (heat period) in cattle can be achieved (this is often performed } \\
\text { on commercial farms), 4) how to palpate and ultrasound the female reproductive tract, 5) how to give oral } \\
\text { rehydration therapy to adult cows, 6) how to perform a commonly required nerve block, 7) how to perform } \\
\text { superovulation (ovulation of a larger than normal number of eggs) and recover embryos (embryos are often } \\
\text { transferred from one cow to another which is the main method of moving genetic mating around the world), } \\
\text { 8) how to perform various methods of restraint and give oral medication, 9) how to examine the udder } \\
\text { and draw milk samples, 10) how to take blood samples At the end, students will be examined on all aspects } \\
\text { of clinical competence." }\end{array}$ \\
\hline
\end{tabular}

Tab. 5: Examples of alternatives for each of the types of procedures on animals for educational or training purposes identified in the non-technical summaries

\begin{tabular}{|c|c|c|c|}
\hline Line no. & Alternative & Description & Source \\
\hline \multicolumn{4}{|c|}{ Behavioral experiments } \\
\hline 1 & Description of the forced swim test & Video and protocol & Yankelevitch-Yahav et al., 2015 \\
\hline 2 & Description of the tail suspension test & Video and protocol & Can et al., 2012 \\
\hline 3 & $\begin{array}{l}\text { Association for the Study of Animal } \\
\text { Behaviour: teaching resources }\end{array}$ & Presentations and videos & $\begin{array}{l}\text { https://www.asab.org/higher- } \\
\text { education-resources }\end{array}$ \\
\hline 4 & LivingLinks: online learning packs & $\begin{array}{l}\text { Presentations, videos and audio } \\
\text { recordings }\end{array}$ & https://living-links.org/resources \\
\hline 5 & Methods for Animal Behavior Research & Video & $\begin{array}{l}\text { https://www.aza.org/methods- } \\
\text { for-animal-behavior-research-dvd }\end{array}$ \\
\hline 6 & Stimulus Response & Video & https://www.stem.org.uk/rx3335 \\
\hline 7 & $\begin{array}{l}\text { Centre for Animal Welfare Science } \\
\text { Excellence: video resources }\end{array}$ & Video & $\begin{array}{l}\text { https://www.animalwelfarescience.com/ } \\
\text { resources-and-media/video }\end{array}$ \\
\hline 8 & $\begin{array}{l}\text { Rabbits and Their Relatives: Health } \\
\text { and Management }\end{array}$ & $\begin{array}{l}\text { Computer resource containing text, } \\
\text { photos and video }\end{array}$ & http://www.wildlifeinformation.org \\
\hline 9 & Sniffy the Virtual Rat & Laboratory simulation software & $\begin{array}{l}\text { http://www.wadsworth.com/ } \\
\text { psychology_d/templates/student__ } \\
\text { resources/0534633609_sniffy2/sniffy/ } \\
\text { main.htm }\end{array}$ \\
\hline 10 & CyberRat & Interactive digital video presentation & http://www.CyberRat.net \\
\hline \multicolumn{4}{|c|}{ Physiology experiments } \\
\hline 11 & SimHeart, SimVessel, Drug Laboratory & $\begin{array}{l}\text { Physiology and pharmacology } \\
\text { experiments in virtual laboratories }\end{array}$ & http://www.virtual-physiology.com \\
\hline 12 & Nerve Physiology & $\begin{array}{l}\text { A computer simulation of experiments } \\
\text { which may be performed on isolated frog } \\
\text { sciatic nerve }\end{array}$ & http://sheffbp.co.uk/nervephys.html \\
\hline 13 & PhysioEx & Laboratory simulation software & https://www.pearson.com.au \\
\hline 14 & Monash University & Online interactive simulations & $\begin{array}{l}\text { https://ilearn.med.monash.edu.au/ } \\
\text { physiology/experiments.html }\end{array}$ \\
\hline
\end{tabular}




\begin{tabular}{|c|c|c|c|}
\hline \multicolumn{4}{|c|}{ Bovine insemination and pregnancy diagnosis training } \\
\hline 15 & Henryetta & Artificial insemination training cow & $\begin{array}{l}\text { https://www.minitube.com/products/ } \\
\text { bovine/education-materials/training- } \\
\text { model-cow-henryetta-holstein-design }\end{array}$ \\
\hline 16 & Bovine Breeder & Artificial insemination simulator & $\begin{array}{l}\text { https://www.realityworks.com/product/ } \\
\text { bovine-breeder-artificial-insemination- } \\
\text { simulator/ }\end{array}$ \\
\hline 17 & Haptic Cow, Haptic Horse & Virtual reality simulator of reproductive tract & http://www.live.ac.uk/haptic-cow \\
\hline \multicolumn{4}{|c|}{ Skills training } \\
\hline 18 & Mimicky Mouse ${ }^{\circledR}$ & $\begin{array}{l}\text { Mouse simulator for training handling, } \\
\text { oral and caudal vein administration }\end{array}$ & $\begin{array}{l}\text { http://www.mitaka-supply.com/mimicky/ } \\
\text { en_index.php }\end{array}$ \\
\hline 19 & Rat training simulator & $\begin{array}{l}\text { Model for training handling and } \\
\text { procedural competencies }\end{array}$ & $\begin{array}{l}\text { https://www.bioseblab.com/en/ } \\
\text { experimental-models/583-rat-training- } \\
\text { simulator.html }\end{array}$ \\
\hline 20 & Mimolette Lab Rat Manikin & $\begin{array}{l}\text { Simulator for training intubation and blood } \\
\text { collection }\end{array}$ & $\begin{array}{l}\text { http://rescuecritters.com/product/ } \\
\text { mimolette-mee-moh-let-lab-rat/ }\end{array}$ \\
\hline 21 & Critical Care Fluffy / Jerry & $\begin{array}{l}\text { Feline / canine manikin for practicing } \\
\text { restraint, bandaging, venipuncture, } \\
\text { resuscitation }\end{array}$ & $\begin{array}{l}\text { https://rescuecritters.com/product/ } \\
\text { critical-care-fluffy/; } \\
\text { http://rescuecritters. } \\
\text { com/product/critical-care-jerry/ }\end{array}$ \\
\hline 22 & Virtual patients & $\begin{array}{l}\text { Online learning within veterinary } \\
\text { curriculum }\end{array}$ & Vogt et al., 2019 \\
\hline \multicolumn{4}{|c|}{ Surgical training - human medicine } \\
\hline 23 & SynDaver ${ }^{\circledR}$ Surgical Model & $\begin{array}{l}\text { Full-body surgical simulator with } \\
\text { functional musculoskeletal, cardiovascular, } \\
\text { respiratory and gastrointestinal systems }\end{array}$ & $\begin{array}{l}\text { https://syndaver.com/product/ } \\
\text { syntissue-surgical-model/ }\end{array}$ \\
\hline 24 & TraumaMan & $\begin{array}{l}\text { Surgical simulator for training, e.g., } \\
\text { chest tube insertion, pneumothorax, } \\
\text { tracheostomy, etc. }\end{array}$ & $\begin{array}{l}\text { https://www.simulab.com/products/ } \\
\text { traumaman-surgical-simulator }\end{array}$ \\
\hline 25 & LAP Mentor & Laparoscopic simulator & $\begin{array}{l}\text { https://simbionix.com/simulators/ } \\
\text { lap-mentor/ }\end{array}$ \\
\hline 26 & Ligating and Suturing Practice Pad & $\begin{array}{l}\text { Pad with a simulated system of vessels to } \\
\text { train suturing while a patient is bleeding }\end{array}$ & $\begin{array}{l}\text { https://surgireal.com/collections/ } \\
\text { human-simulation/products/ } \\
\text { realflow-suture-pad }\end{array}$ \\
\hline 27 & Touch Surgery & Surgical simulation and video platform & https://www.touchsurgery.com/ \\
\hline 28 & Fundamental Surgery & Virtual reality surgical simulation platform & https://www.fundamentalsurgery.com/ \\
\hline \multicolumn{4}{|c|}{ Surgical training - veterinary medicine } \\
\hline 29 & Canine Dental Surgical Simulator & Simulator for practising canine surgery & $\begin{array}{l}\text { https://vetsimulators.com/ } \\
\text { caninedentalsimulator/ }\end{array}$ \\
\hline 30 & SynDaver & Canine surgical model & $\begin{array}{l}\text { https://syndaver.com/product-tag/ } \\
\text { 5-veterinary/ }\end{array}$ \\
\hline 31 & DASIE & $\begin{array}{l}\text { Dog abdominal surrogate for instructional } \\
\text { exercise }\end{array}$ & $\begin{array}{l}\text { http://www.dasiesurgery.ca/DASIE/ } \\
\text { DASIE.html }\end{array}$ \\
\hline 32 & Microsurgical Developments PVC-Rat & Model to train skills in microsurgery & $\begin{array}{l}\text { http://www.microdev.nl/index.php/ } \\
\text { products/md-pvc-rat }\end{array}$ \\
\hline 33 & $\begin{array}{l}\text { 3D Printed Biomimetic Rabbit Airway } \\
\text { Simulation Model }\end{array}$ & Model for nasotracheal intubation training & Oberoi et al., 2020 \\
\hline 34 & Bovine Vascular Access Model & $\begin{array}{l}\text { Model for teaching students a technique } \\
\text { for placing catheter in the auricular vein } \\
\text { of cattle }\end{array}$ & Giese et al., 2015 \\
\hline
\end{tabular}




\begin{tabular}{|c|c|c|c|}
\hline \multicolumn{4}{|c|}{ Other (anatomy) } \\
\hline 35 & Interspectral & Virtual dissection & $\begin{array}{l}\text { https://interspectral.com/what-we-do/ } \\
\text { education }\end{array}$ \\
\hline 36 & Anatomage & Human anatomy $3 \mathrm{D}$ visualization tool & $\begin{array}{l}\text { https://www.anatomage.com/ } \\
\text { anatomage-medical// }\end{array}$ \\
\hline 37 & zSpace & Virtual reality dissections & https://zspace.com/post-secondary/ \\
\hline 38 & eMind & Virtual dissection & https://emindweb.com/products.php \\
\hline 39 & V-Frog & Virtual dissection & http://www.tactustech.com/vfrog/ \\
\hline 40 & $\begin{array}{l}\text { Interactive Veterinary Education Tool } \\
\text { (IVET) }\end{array}$ & $\begin{array}{l}\text { Web-based e-learning platform with 2D } \\
\text { and 3D images of body anatomy }\end{array}$ & Xiberta and Boada, 2019 \\
\hline
\end{tabular}

ing animals instead of capturing wildlife. Many institutions already provide online learning resources, such as presentations and animal audio and video recordings (Tab. 5, lines 3-10). Examples include the "Stimulus Response" video produced by the Association for the Study of Animal Behaviour, which investigates learning behavior and how animals respond to stimuli in their environments ${ }^{2}$ and videos of farmed animal behavior by The Centre for Animal Welfare Science Excellence ${ }^{3}$. The computer software resource "Rabbits and Their Relatives: Health and Management" contains information about behavior and behavioral requirements of domestic rabbits (Oryctolagus cuniculus) and their wild relatives (rabbits, hares and pikas) through text, photos and video clips ${ }^{4}$.

Additionally, software simulations can provide an interactive training experience. Sniffy the Virtual Rat is a computer program featuring a realistic and interactive laboratory rat in a Skinner box, described as "Rattus siliconus". The Sniffy program allows students to design and complete training programs using central behavioral principles such as classical and operant conditioning (Graham et al., 1994). CyberRat is a similar learning tool comprised of video clips of a real laboratory rat in an interactive digital video presentation ${ }^{5}$. Learning principles can also be taught using human demonstrations, which students have reported as being useful and enjoyable (Lewis, 2015).

\subsubsection{Experiments in physiology}

Drug disposition, pharmacokinetics and mechanisms of action can be easily demonstrated through simulators (e.g., Tab. 5, line 11, and ADAM (Zuna and Holt, 2017); see the example in Tab. 4, line 3). The Sheffield BioScience Programs developed Nerve Physiology, an interactive program that simulates several experiments performed on the frog sciatic nerve (Tab. 5, line 12; see the example in Tab. 4, line 4). Australia's Monash University (Tab. 5 , line 14) has established a suite of online interactive practical simulations for physiology classes (Quiroga et al., 2016). There are also other commercially available physiology simulators, e.g., PhysioEx and products from Virtual Physiology (Tab. 5, lines 13 and 11 , respectively). If a purpose- or species-specific simulator is not accessible, researchers may use the developed tools to build their own web-based simulators (Šilar et al., 2019) and conduct demonstrations through video documentation of previously conducted experiments (see the example in Tab. 4, line 5).

\subsubsection{Insemination and pregnancy diagnosis training}

Out of 23 NTSs on insemination and pregnancy diagnosis training, 21 were performed on cows (see the example in Tab. 4, line 6). Breed'n Betsy (Baillie et al., 2005a,b) was one of the first simulators, followed by the more advanced technology implemented in Haptic Cow and Haptic Horse (Baillie et al., 2010). Haptic technology applies anatomically-appropriate pressure to students' fingertips, allowing them to palpate (feel) their way around a virtual simulation (Tab. 5, lines 15-17). The instructor is typically able to observe students' actions on a computer screen and to program the simulation to exhibit different physiological or pathological states (e.g., different stages of pregnancy).

\subsubsection{Skills training}

Animals are used for skills training of veterinarians, medical doctors, and also personnel working with laboratory animals, mostly rodents. Clinical skills laboratories have been established in many veterinary and medical schools to teach surgical and medical skills, clinical problem-solving, teamwork, and communication, using models, manikins, simulators, and patient actors (Bradley, 2006; Becker, 2007; Grevemeyer and Knight, 2018). Several training simulators are available to train handling skills, venipuncture, intubation or resuscitation techniques that can replace the procedures on animals for educational or training purposes set out in the examples in Tab. 4, lines 7-8. While simulators of rodents seem to be most common, mannequins representing other species are also available (Tab. 5, lines 18-21).

\footnotetext{
2 https://www.stem.org.uk/rx3335

3 https://www.animalwelfarescience.com/resources-and-media/video

4 http://www.wildlifeinformation.org

5 http://www.cyberrat.net
} 


\subsubsection{Human surgical training}

Simulation-based training in healthcare has long become an important element between student lectures and proficient clinical practice (Al-Elq, 2010; Meurling et al., 2013; Marker et al., 2019). Historically, medical students trained using cadaveric dissections and clinical practice under the supervision of experienced physicians and surgeons (Wijewickrema et al., 2018). However, today's demand for both student and patient-centered practices and more efficient training programs has led to the development of educational and training programs and environments that allow trainees to acquire competencies adapted to their level and needs (Atesok et al., 2017; Feins et al., 2017; Wijewickrema et al., 2018; Rathod et al., 2019; Villanueva et al., 2019; Aydin et al., 2020). Advanced models using human cadavers that can be connected to artificial blood reservoirs are still used, creating a model that simulates live surgery in terms of bleeding and pulsation (Aboud et al., 2004, 2015; Duhem et al., 2019). Virtual reality simulators (Davies et al., 2013; Cagiltay et al., 2019) and full- and partial-body training simulators such as TraumaMan (Hall et al., 2014), SimMan 3G (Silverplats et al., 2016) or their low-cost alternative SurgeMan (Garcia et al., 2019) provide the technology to fulfil training needs, evaluation of individual technical skills, and team training on non-technical skills. 3D printing has also been implemented to create models for training, for example, cervical laminectomy or pediatric emergency procedures (Kovatch et al., 2020; Tanya and Dubrowski, 2020). These and other simulators are currently used to train surgeons to perform various routine operations in order to learn the appropriate skills for interventions on real patients (Tab. 5, lines 23-25; see the example in Tab. 4, line 9). Tissue suture can be practiced on silicone models (Tab. 5, line 26), some of them with simulated blood (da Silva et al., 2019). A recent systematic review of non-biological microvascular surgery simulators found 20 basic prosthetic models, 20 intermediate models, 13 advanced models, and six virtual reality simulators available for microvascular surgery training (Abi-Rafeh et al., 2019; see example in Tab. 4, line 10).

\subsubsection{Veterinary medical training}

The use of animals is an integral part of veterinary medical education (see the examples in Tab. 4, lines 11-12). For learning veterinary medical procedures, several e-learning platforms have been developed, e.g., by the University of Girona (Xiberta and Boada, 2019), University of Hannover (Müller et al., 2019), or Freie Universität Berlin (Vogt et al., 2019; Tab. 5, line 22). Multiple surgical simulators are also available (Tab. 5, lines 29-34).

As described in Knight $(2011,2012)$, humane surgical training courses have been introduced within many veterinary schools. These ideally comprise several stages. First, students learn basic manual skills such as suturing and instrument handling, using knot-tying boards, plastic organs, and similar models (Tab. 5). Students then progress to simulated surgery on ethically sourced cadavers or full-body or virtual simulators. Major organs may also be perfused with simulated blood via pulsatile pumps (de Souza and Matera, 2015), simulating bleeding and allowing hemostatic practice (control of bleeding). Finally, students observe, assist with, and then perform necessary surgery under close supervision on real patients that benefit from the surgery, similar to the manner in which physicians are trained.

\section{Discussion}

\subsection{Missing information in non-technical summaries}

We have identified several concerns with the assessed NTSs in terms of the quality of the information provided. First, there seems to be inconsistency between the numbers reported in the national statistical reports and the numbers reported in the NTSs. For example, Luxembourg reported the use of 144 animals for educational purposes in 2017 (Tab. 1), but we were not able to find any relevant NTSs (Tab. 3). Another example is Germany, which has one of the highest numbers of animals used (2017: 53,121; 2018: 55,386; Tab. 1), but we found only a couple of NTSs describing solely educational procedures (Tab. 3), which were expected to use a total of 24 animals in 2017 and 1,260 in 2018. This could be explained by the fact that in Germany there is no legal obligation for projects involving the use of animals for the primary purpose of training or education to be subjected to the usual authorization procedure. These projects only have to be reported to the authorities ${ }^{6}$. Second, 24 out of 249 NTSs across 7 Member States did not address the required question about the 3Rs and, in particular, how replacement was considered. Lastly, we had difficulties in finding NTSs from some of the Member States. At the time of writing this article, several Member States either did not have a functioning link to their NTSs listed on the European Commission's website or their latest NTSs were more than four years old (Tab. 3). Therefore, there is an issue with irregular and slow publication of NTSs, a problem that has been already reported previously (Taylor et al., 2018). To increase the transparency of animal use, NTSs need to be published regularly, be easily accessible, and strictly follow the template provided by the EU (EC, 2013).

Hopefully, the current lapses in reporting will be remedied by the recently implemented decision EU 2020/569 of the European Commission, "establishing a common format and information content for the submission of the information to be reported by the Member States according to the Directive 2010/63/EU of the European Parliament and the Council on the protection of animals used for scientific purposes and repealing Commission Implementing Decision 2012/707/EU'7. 


\subsection{Justifications for continued animal use in education and training}

The two main reasons given to assert that replacement was not possible, were that "practice on a living animal is necessary for 'proper' learning" and "no adequate model/alternative is currently available" (Fig. 2). Admittedly, it may not be possible to learn certain skills without ever touching a living animal or human. Animal use is certainly needed to practice handling and to gain experience within veterinary education and laboratory animal science, as practice with human beings is necessary for medical education. However, it is important not to inflict unnecessary harm and to promote training programs that could be helpful for animals in addition to the benefits for humans. Veterinary clinical rotations provide one example in which procedures are genuinely intended to benefit animal patients. Another example is provided by animal shelter neutering programs, which are a popular component of humane veterinary surgical courses worldwide as they allow students to gain invaluable experience on some of the most common procedures they will later perform in practice (Richardson et al., 1994; Howe and Slater, 1997). Additionally, the number of unwanted animals killed due to uncontrolled breeding and a subsequent lack of homes is decreased, and neutered animals are more likely to be adopted (Clevenger and Kass, 2003).

We were able to identify several examples of educational and training methods and tools that are currently available for the intended learning outcomes (Tab. 5) and that do not involve the harmful use of animals. There has been a boom in the industry of educational animal-free alternatives: virtual dissection simulations, 3D models, plastinated specimens, videos, or online presentations (Martinsen and Jukes, 2005; Knight, 2007, 2012; Oakley, 2012; Zemanova and Knight, 2021). This diversity of resources allows greater flexibility without compromising the teaching and learning of hands-on skills (Valliyate et al., 2012). Furthermore, with the technologies available today and the rapid evolution of research, veterinary and clinical practices, educational curricula and methods need to be able to promptly adapt to new training needs.

There may be also other reasons for the limited uptake of alternatives that are not mentioned by the authors of the NTSs: resistance from the faculty to change and use alternatives that they themselves did not develop or lack of resources, time or skill for implementation (Dewhurst, 2008; Knight, 2011).

\subsection{Are existing models adequate?}

There is significant evidence that alternatives can replace many of the identified learning outcomes from procedures on animals for educational or training purposes, such as knowledge and skills acquisition, experimental design, and teamwork (Knight, 2007; Patronek and Rauch, 2007; Dewhurst, 2008; Rosen et al., 2010; Quilici et al., 2015). The first studies on the effectiveness of filmbased instructional activities as dissection alternatives had already emerged by the 1960s (Fowler and Brosius, 1968; De Villiers and Monk, 2005). More recently, Durand et al. (2019) reported that there was no difference in the final grades of students learning about physiology through virtual classes and students learning through animal laboratory classes. Rezende-Filho et al. (2014) re- ported on a student-centered approach to active learning through the construction of teaching tools in medical physiology. Other studies have found high-fidelity models and simulators realistic, engaging and efficient, and that such training has good transferability to clinical settings (Kinnison et al., 2009; Salas et al., 2009; Grant et al., 2010; Griswold et al., 2012; Marker et al., 2019; Yong et al., 2019; Jaskowski et al., 2020). The systematic review by McLaughlin et al. (2019) revealed that "simulation-based training for trauma resuscitation is associated with improved measures of teamwork, task performance and speed, knowledge and provider satisfaction". Today, more than $99 \%$ of all advanced trauma life support training institutions in the USA use simulators exclusively (Pawlowski et al., 2018). In 2006, Draycott and colleagues showed for the first time that simulation-based training was associated with improved management and clinical outcomes of the trained scenarios (Draycott et al., 2006).

Although there are several alternatives available to learn how to handle rodents and gain procedural competencies (Tab. 5), we noticed that simulation-based training in laboratory animal science is still at an early stage of implementation when compared to healthcare education. For example, research and development in education and training in laboratory animal science is behind in the range of scenarios and the fidelity of simulators available, as well as in the evaluation of learning outcomes, showing that more investment is needed to promote the use of alternatives in this area. However, for any acquisition of skills that will be necessary in future clinical or laboratory practice, simulation-based training without harmful use of animals or humans has proven to be an adaptable methodology to meet any training needs and a suitable practice to improve the knowledge and skills of trainees and the outcomes of patients (Salas et al., 2009; Grant et al., 2010; Griswold et al., 2012; Rubeis and Steger, 2018; Marker et al., 2019; Yong et al., 2019).

\subsection{Other concerns associated with continued animal use in education}

\subsubsection{Harm to the animal}

Surgical training in human medicine is normally a non-recovery procedure, i.e., the animal is killed during (normally at the end of) the teaching activity. Whether death is harmful to an animal if inflicted without pain or distress, was often contested historically. Modern conceptualizations of animal welfare, however, understand that good welfare requires not just the avoidance of negative states, but the experience of positive states. Death permanently prevents such positive states and, indeed, the achievement of any other interests animals could seek to fulfil during the remainder of their lives (Balluch, 2006). Accordingly, it is reasonable to conclude that death is one of the most profound harms that can be inflicted (Kaldewaij, 2006; Yeates, 2010; Jensen, 2017), barring exceptional cases such as genuine euthanasia of those faced with severe, ongoing suffering with a poor prognosis for recovery.

Other non-lethal educational practices can also be harmful to an animal. For instance, transrectal palpation training has been shown to increase cortisol levels in cows (Nakao et al., 1994; 
Cingi et al., 2012; Giese et al., 2018) and horses (Ille et al., 2016; van Vollenhoven et al., 2017), suggesting that the experience is stressful for the animals.

\subsubsection{Harm to the student}

Veterinary students are drawn to their field of study by their strong interest in animal health and well-being. They can experience stress during their education if they are required to practice painful techniques and terminal surgery (Capaldo, 2004; Gelberg and Gelberg, 2005). Some students may even suffer psychological trauma as a result of engaging in what they perceive as ethically objectionable activities (Capaldo, 2004). The loss of highly qualified people who may forgo a career in science in order not to compromise their values is especially problematic (Capaldo, 2004).

On the other hand, if students are forced to cause suffering to animals during their learning experience, this may lead to "compassion fatigue". This is a condition characterized by a diminished ability to empathize or feel compassion for others (Pereira et al., 2017). Arluke and Hafferty (1996) showed that learning experiences perceived as morally wrong initially lead to ethical uneasiness but ultimately to desensitization through using absolutions justifying the act. Similarly, the decreasing awareness of veterinary students of animal sentience (specifically, the hunger, pain, fear and boredom of dogs, cats and cows) throughout their veterinary courses (Paul and Podberscek, 2000), the decreased likelihood of fourth-year students to provide analgesia when compared to second- or third-year students (Hellyer et al., 1999), and the inhibition of normal development of moral reasoning ability during the four years of veterinary school (Self et al., 1991), have all been revealed within veterinary student cohorts. These are all examples of desensitization-related phenomena. They are actually psychological adaptations to "cognitive dissonance", a discordance between behavior and beliefs (Engel et al., 2020; Pirrone et al., 2019). In this case, the behavior is harmful educational animal use and the belief is that animals are sentient and should not be harmed. Humans normally resolve such dissonance by altering either behavior or beliefs. When altering behavior is not an option - because students fear that refusal to participate could threaten their careers - then beliefs can change, with such desensitization-related phenomena resulting. These adaptations resolve the dissonance and enable previously caring students to withstand what could otherwise be the intolerable psychological stresses that result from being required to harm and kill sentient creatures in the absence of overwhelming necessity (Capaldo, 2004). However, these constitute harms to students and, potentially, risks to their future patients, when veterinarians are subsequently less likely to consider animals as sentient or to warrant appropriate analgesia.

\subsubsection{High financial costs}

Institutions that use animals for education and training incur costs for caring for animals, such as expenses for veterinary staff, supplies, anesthesia, feeding and disposal. In addition, training procedures may involve the purchase of equipment for each of the student workstations (Graham et al., 1994). Financial barriers related to using live animals were one of the main motiva- tions for creating Sniffy, the Virtual Rat (Graham et al., 1994). Low-technology simulators have the advantage that they can often be easily reproduced by teachers and educators themselves at low cost, which can be particularly important in conditions with a lack of funds and/or when dealing with many students (Adams et al., 2018; Crawford et al., 2019). More expensive tools can also be cost-effective over the longer term. For instance, Gala and Crandall (2019) reported that the introduction of the TraumaMan simulator in advanced trauma life support courses can lead to savings of 25-60 USD per student per year.

\subsubsection{Breach of legislation}

Article 4 of EU Directive 2010/63 states that: "Member States shall ensure that, wherever possible, a scientifically satisfactory method or testing strategy, not entailing the use of live animals, shall be used instead of a procedure." This Directive has been transposed into national legislation within all EU Member States and was fully implemented by 2013 . Our results indicate that in many instances the authors of the NTSs failed to either adequately search for alternatives (e.g., those listed in Tab. 5) or failed to report and implement the results of these searches. This failure to replace animals when there are suitable alternatives available thus indicates non-compliance with the Directive. The "lack of necessity" argument needs to be strictly implemented: "if alternatives exist, animal sacrifice is unnecessary" (De Villiers and Monk, 2005).

\section{Conclusion}

Between 2014 and 2018, an estimated 124,000 to 172,000 animals were used for educational purposes among the EU and EEA Members States. This is probably an under-estimate, as several countries did not report figures. In view of our results, the use of a large number of these animals could likely have been avoided. Our data appears to indicate that the potential for implementing alternatives has not been fully met and that considerable room for improvement exists. We hope this study will serve as an incentive for educators, universities and funding agencies to support the development and implementation of non-harmful alternatives and curricula in life sciences education and training. We also hope this study will help governments and competent authorities to put in place national policies to replace the use of animals for the purposes of education and training, as well as to effectively evaluate possible replacement alternatives for projects aiming at using animals for educational and training purposes. Wider discussions about and promotion of these alternatives in education and training are crucial for establishing a culture of life and health sciences education that is ethical and compassionate.

\section{References}

Abi-Rafeh, J., Zammit, D., Jaberi, M. M. et al. (2019). Nonbiological microsurgery simulators in plastic surgery training: A systematic review. Plast Reconstr Surg 144, 496e-507e. doi:10.1097/PRS.0000000000005990 
Aboud, E., Suarez, C. E., Al-Mefty, O. et al. (2004). New alternative to animal models for surgical training. Altern Lab Anim 32, Suppl 1B, 501-507. doi:10.1177/026119290403201s80

Aboud, E. T., Aboud, G. and Aboud, T. (2015). "Live cadavers" for practicing airway management. Mil Med 180, Suppl 3, 165170. doi:10.7205/MILMED-D-14-00396

Adams, C. M., Nigrovic, L. E., Hayes, G. et al. (2018). Teaching incision and drainage: Perceived educational value of abscess models. Pediatr Emerg Care 34, 174-178. doi:10.1097/ PEC.0000000000001240

Akbarsha, M. A. (2007). Movement to curtail animal dissections in zoology curriculum: Review of the Indian experience. ALTEX 24, 163-166. doi:10.14573/altex.2007.3.163

Akbarsha, M. A., Zeeshan, M. and Meenakumari, K. J. (2013). Alternatives to animals in education, research, and risk assessment: An overview with special reference to Indian context. ALTEX Proc 2, 5-19. https://proceedings.altex.org/data/ 2013-01/rISC_001_Akbarsha2.pdf

Al-Elq, A. H. (2010). Simulation-based medical teaching and lee arning. J Family Community Med 17, 35-40. doi:10.4103/13191683.68787

Arluke, A. and Hafferty, F. (1996). From apprehension to fascination with "dog lab": The use of absolutions by medical students. J Contemp Ethnogr 25, 201-225. doi:10.1177/ 089124196025002002

Atesok, K., Satava, R. M., Marsh, J. L. et al. (2017). Measuring surgical skills in simulation-based training. J Am Acad Orthop Surg 25, 665-672. doi:10.5435/JAAOS-D-16-00253

Aydin, A., Ahmed, K., Van Hemelrijck, M. et al. (2020). LBA0105 simulation in urological training and education (SIMULATE): An international randomised controlled clinical and educational trial to determine the effect of simulation-based surgical training. J Urol 203, e1021-e1021. doi:10.1097/JU. 0000000000000946.05

Baillie, S., Crossan, A., Brewster, S. A. et al. (2005a). Validation of a bovine rectal palpation simulator for training veterinary students. Stud Health Technol Inform 111, 33-36. http://eprints. gla.ac.uk/3729/

Baillie, S., Mellor, D. J., Brewster, S. A. et al. (2005b). Integrating a bovine rectal palpation simulator into an undergraduate veterinary curriculum. $J$ Vet Med Educ 32, 79-85. doi:10.3138/ jvme.32.1.79

Baillie, S., Crossan, A., Brewster, S. A. et al. (2010). Evaluating an automated haptic simulator designed for veterinary students to learn bovine rectal palpation. Simul Healthc 5, 261266. doi:10.1097/SIH.0b013e3181e369bf

Balls, M. (2018). Replacing animal use in education and training. Altern Lab Anim 46, 107-108. doi:10.1177/ 026119291804600303

Balluch, M. (2006). Animals have a right to life. ALTEX 23, 281293. https://www.altex.org/index.php/altex/article/view/804

Becker, G. J. (2007). Simulation and the coming transformatih on of medical education and training. Radiology 245, 7-9. doi: 10.1148/radiol.2451070674

Bishop, L. J. and Nolen, A. L. (2001). Animals in research and education: Ethical issues. Kennedy Inst Ethics J 11, 91-112. doi:10.1353/ken.2001.0006

Bradley, P. (2006). The history of simulation in medical education and possible future directions. Med Educ 40, 254-262. doi:10.1111/j.1365-2929.2006.02394.x

Cagiltay, N. E., Ozcelik, E., Isikay, I. et al. (2019). The effect of training, used-hand, and experience on endoscopic surgery skills in an educational computer-based simulation environment (ECE) for endoneurosurgery training. Surg Innov 26, 725-737. doi:10.1177/1553350619861563

Can, A., Dao, D. T., Terrillion, C. E. et al. (2012). The tail suspension test. JoVE, e3769. doi:10.3791/3769

Capaldo, T. (2004). The psychological effects on students of using animals in ways that they see as ethically, morally or religiously wrong. Altern Lab Anim 32, Suppl 1B, 525-531. doi:10. 1177/026119290403201s85

Cingi, C. C., Baser, D. F., Karafakioglu, Y. S. et al. (2012). Stress response in dairy cows related to rectal examination. Acta Scientiae Veterinariae 40, 1053. https://www.redalyc.org/ pdf/2890/289023557008.pdf

Clevenger, J. and Kass, P. H. (2003). Determinants of adoption and euthanasia of shelter dogs spayed or neutered in the University of California veterinary student surgery program compared to other shelter dogs. J Vet Med Educ 30, 372-378. doi:10.3138/jvme.30.4.372

Coombs, C. M., Shields, R. Y., Hunt, E. A. et al. (2017). Design, implementation, and evaluation of a simulation-based clinical correlation curriculum as an adjunctive pedagogy in an anatomy course. Acad Med 92, 494-500. doi:10.1097/ ACM.0000000000001387

Crawford, S. B., Huque, Y. I., Austin, D. E. et al. (2019). Development and review of the chest tube high-feedback educational simulation trainer (CHEST). Simul Healthc 14, 276-279. doi: 10.1097/sih.0000000000000361

Crofts, J. F., Bartlett, C., Ellis, D. et al. (2006). Training for shoulder dystocia: A trial of simulation using low-fidelity and high-fidelity mannequins. Obstet Gynecol 108, 1477-1485. doi:10.1097/01.AOG.0000246801.45977.c8

da Silva, A. P. G., Rodriguez, J. E. R., de Oliveira, M. C. et al. (2019). The alternative model of silicone for experimental simulation of suture of living tissue in the teaching of surgical technique. Acta Cir Bras 34, e201900410. doi:10.1590/s0102865020190040000010

Davies, J., Khatib, M. and Bello, F. (2013). Open surgical simulation: A review. J Surg Educ 70, 618-627. doi:10.1016/j. jsurg.2013.04.007

de Souza, M. C. C. M. I. and Matera, J. M. (2015). Bleeding simulation in embalmed cadavers: Bridging the gap between simulation and live surgery. ALTEX 32, 59-63. doi:10.14573/altex. 1407311

De Villiers, R. and Monk, M. (2005). The first cut is the deepest: Reflections on the state of animal dissection in biology education. J Curric Stud 37, 583-600. doi: 10.1080/00220270500041523

Deonarain, A. R., Harrison, R. V., Gordon, K. A. et al. (2020). Live porcine model for surgical training in tracheostomy and open-airway surgery. Laryngoscope 130, 2063-2068. doi:10. 


\section{2/lary.28309}

Dewhurst, D. (2008). Is it possible to meet the learning objectives of undergraduate pharmacology classes with non-animal models? AATEX 14, 207-212. http://www.asas.or.jp/jsaae_old/ aatex/Vol12S.html

Draycott, T., Sibanda, T., Owen, L. et al. (2006). Does training in obstetric emergencies improve neonatal outcome? BJOG 113, 177-182. doi:10.1111/j.1471-0528.2006.00800.x

Duhem, H., Viglino, D., Bellier, A. et al. (2019). Cadaver models for cardiac arrest: A systematic review and perspectives. Resuscitation 143, 68-76. doi:10.1016/j. resuscitation.2019.08.009

Durand, M. d. T., Restini, C. B. A., Wolff, A. C. D. et al. (2019). Students' perception of animal or virtual laboratory in physiology practical classes in PBL medical hybrid curriculum. Adv Physiol Educ 43, 451-457. doi:10.1152/advan. 00005.2019

Engel, R. M., Silver, C. C., Veeder, C. L. et al. (2020). Cognitive dissonance in laboratory animal medicine and implications for animal welfare. J Am Assoc Lab Anim Sci 59, 132138. doi:10.30802/AALAS-JAALAS-19-000073

EC - European Commission (2009). Final report of the expert working group on severity classification of scientific procedures performed on animals. https://ec.europa.eu/environment/ archives/lab_animals/ewg_en.htm

EC (2013). Working document on Non-Technical Project summaries. https://ec.europa.eu/environment/chemicals/lab animals/ pdf/Recommendations\%20for\%20NTS.pdf

EC (2020). 2019 Report on the statistics on the use of animals for scientific purposes in the Member States of the European Union in 2015-2017. Report from the Commission to the European Parliament and the Council. EC.

Feins, R. H., Burkhart, H. M., Conte, J. V. et al. (2017). Simulation-based training in cardiac surgery. Ann Thorac Surg 103, 312-321. doi:10.1016/j.athoracsur.2016.06.062

Fowler, H. S. and Brosius, E. J. (1968). A research study on the values gained from dissection of animals in secondary school biology. Sci Educ 52, 55-57. doi:10.1002/sce.3730520114

Gala, S. G. and Crandall, M. L. (2019). Global collaboration to modernize advanced trauma life support training. J Surg Educ 76, 487-496. doi:10.1016/j.jsurg.2018.08.011

Garcia, D. F. V., Domingues, C. A., Collet e Silva, F. S. et al. (2019). Efficacy of a novel surgical manikin for simulating emergency surgical procedures. Am Surg 85, 1318-1326. http://observatorio.fm.usp.br/handle/OPI/34256

Gelberg, S. and Gelberg, H. (2005). Stress management inter; ventions for veterinary students. J Vet Med Educ 32, 173-181. doi:10.3138/jvme.32.2.173

Giese, H., Hilke, J., Gundelach, Y. et al. (2015). Validation of a bovine vascular access model for teaching students a technique for placing catheter in the auricular vein of cattle. InVeST Conference 2015. https://bit.ly/2RgPbhk

Giese, H., Dilly, M., Gundelach, Y. et al. (2018). Influence of transrectal palpation training on cortisol levels and heart rate variability in cows. Theriogenology 119, 238-244. doi:10. 1016/j.theriogenology.2018.07.016
Giménez, M. E., Garcia Vazquez, A., Davrieux, C. F. et al. (2020). Image-guided surgical training in percutaneous hepatobiliary procedures: Development of a realistic and meaningful bile duct dilatation porcine model. J Laparoendoscopic Adv Surg Tech A, online ahead of print. doi:10.1089/ lap. 2020.0680

Graham, J., Alloway, T. and Krames, L. (1994). Sniffy, the virtual rat: Simulated operant conditioning. Behav Res Methods Instrum Comput 26, 134-141. doi:10.3758/BF03204606

Grant, J. S., Moss, J., Epps, C. et al. (2010). Using videofacilitated feedback to improve student performance following high-fidelity simulation. Clin Simul Nurs 6, e177-e184. doi:10. 1016/j.ecns.2009.09.001

Grevemeyer, B. and Knight, A. (2018). The development of a clinical skills laboratory at Ross University School of Veterinary Medicine. Altern Lab Anim 46, 177-183. doi: 10.1177/026119291804600305

Griswold, S., Ponnuru, S., Nishisaki, A. et al. (2012). The emerging role of simulation education to achieve patient safety: Translating deliberate practice and debriefing to save lives. Pediatr Clin North Am 59, 1329-1340. doi:10.1016/j. pcl.2012.09.004

Guedes, H. G., Câmara Costa Ferreira, Z. M., Ribeiro de Sousa Leão, L. et al. (2019). Virtual reality simulator versus box-trainer to teach minimally invasive procedures: A meta-analysis. Int J Surg 61, 60-68. doi:10.1016/j.ijsu.2018.12.001

Hall, A. B., Riojas, R. and Sharon, D. (2014). Comparison of self-efficacy and its improvement after artificial simulator or live animal model emergency procedure training. Mil Med 179, 320-323. doi:10.7205/milmed-d-12-00446

Hansen, L. A. (2014). Animal laboratories are not needed to train medical students. J Surg Educ 71, 454. doi:10.1016/j. jsurg.2014.02.001

Hardman, J. G. and Ross, J. J. (2006). Modelling: A core technique in anaesthesia and critical care research. Br J Anaesth 97, 589-592. doi:10.1093/bja/ael272

Hart, L. A., Wood, M. W. and Hart, B. L. (2008). Why Dissection? Animal Use in Education. Westport, CT, USA: Greenwood Press.

Hellyer, P., Frederick, C., Lacy, M. et al. (1999). Attitudes of veterinary medical students, house officers, clinical faculty, and staff toward pain management in animals. $J$ Am Vet Med Assoc 214, 238-244. https://europepmc.org/article/med/9926017

Howe, L. M. and Slater, M. R. (1997). Student assessment of the educational benefits of a prepubertal gonadectomy program (preliminary findings). J Vet Med Educ 24, 12-17. https://bit. ly/3xH2g4c

Ille, N., Aurich, C. and Aurich, J. (2016). Physiological stress responses of mares to gynecologic examination in veterinary medicine. J Equine Vet Sci 43, 6-11. doi:10.1016/j.jevs. 2016.04.010

Jaskowski, J. M., Sobolewski, J., Wieczorkiewicz, M. et al. (2020). Modern techniques of teaching bovine rectal palpation: Opportunities, benefits and disadvantages of new educational devices. Med Weter 76, 5-10. doi:10.21521/mw.6324

Jensen, K. K. (2017). How should death be taken into account 
in welfare assessments? J Agric Environ Ethics 30, 615-623. doi:10.1007/s10806-017-9688-1

Jukes, N. (2004). Are animals necessary in biological education? Altern Lab Anim 32, Suppl 1B, 753-754. doi:10. 1177/026119290403201s124

Kaldewaij, F. (2006). Animals and the harm of death. In M. Kaiser and M. E. Lien (eds.), Ethics and the Politics of Food. Oslo, Norway: Congress of the European Society for Agricultural and Food Ethics.

Kinnison, T., Forrest, N. D., Frean, S. P. et al. (2009). Teaching bovine abdominal anatomy: Use of a haptic simulator. Anat Sci Educ 2, 280-285. doi:10.1002/ase.109

Knight, A. (2007). The effectiveness of humane teaching methods in veterinary education. ALTEX 24, 91-109. doi:10.14573/ altex.2007.2.91

Knight, A. (2011). The Costs and Benefits of Animal Experiments. Basingstoke, UK: Palgrave Macmillan.

Knight, A. (2012). The potential of humane teaching methods within veterinary and other biomedical education. ALTEX Proc 1, 365-375. doi:10.14573/altex.2007.2.91

Kovatch, K. J., Powell, A. R., Green, K. et al. (2020). Development and multidisciplinary preliminary validation of a 3-dimensional-printed pediatric airway model for emergency airway front-of-neck access procedures. Anesth Analg 130, 445451. doi:10.1213/ane.0000000000003774

Kuhse, H. and Singer, P. (1998). A Companion to Bioethics. Malden, MA, USA: Blackwell Publishing.

Labrague, L. J., McEnroe-Petitte, D. M., Bowling, A. M. et al. (2019). High-fidelity simulation and nursing students' anxiety and self-confidence: A systematic review. Nurs Forum 54, 358-368. doi:10.1111/nuf.12337

Lewis, J. L. (2015). A comparison between two different activities for teaching learning principles: Virtual animal labs versus human demonstrations. Scholarsh Teach Learn Psychol 1, 182. doi:10.1037/st10000013

Marker, S., Mohr, M. and Østergaard, D. (2019). Simulation-based training of junior doctors in handling critically ill patients facilitates the transition to clinical practice: An interview study. BMC Med Educ 19, 11. doi:10.1186/s12909-0181447-0

Martinsen, S. and Jukes, N. (2005). Towards a humane veterinary education. $J$ Vet Med Educ 32, 454-460. doi:10.3138/ jvme.32.4.454

McLaughlin, C., Barry, W., Barin, E. et al. (2019). Multidisciplinary simulation-based team training for trauma resuscitation: A scoping review. J Surg Educ 76, 1669-1680. doi:10. 1016/j.jsurg.2019.05.002

Meurling, L., Hedman, L., Sandahl, C. et al. (2013). Systematic simulation-based team training in a Swedish intensive care unit: A diverse response among critical care professions. $B M J$ Qual Saf 22, 485-494. doi:10.1136/bmjqs-2012-000994

Moher, D., Liberati, A., Tetzlaff, J. et al. (2009). Preferred repor; ting items for systematic reviews and meta-analyses: The PRISMA statement. PLoS Med 6, e1000097. doi:10.1371/journal. pmed. 1000097

Müller, L. R., Tipold, A., Ehlers, J. P. et al. (2019). TiHoVideos:
Veterinary students' utilization of instructional videos on clinical skills. BMC Vet Res 15, 326. doi:10.1186/s12917-0192079-2

Nakao, T., Sato, T., Moriyoshi, M. et al. (1994). Plasma cortisol response in dairy cows to vaginoscopy, genital palpation per rectum and artificial insemination. J Vet Med A Physiol Pathol Clin Med 41, 16-21. doi:10.1111/j.1439-0442.1994.tb00060.x

Oakley, J. (2012). Science teachers and the dissection debate: Perspectives on animal dissection and alternatives. Int J Environ Sci Educ 7, 253-267. doi:10.1080/21548455.2016.1254358 Oakley, J. (2013). "I didn't feel right about animal dissection". Dissection objectors share their science class experiences. Soc Anim 21, 360-378. doi:10.1163/15685306-12341267

Oberoi, G., Eberspächer-Schweda, M. C., Hatamikia, S. et al. (2020). 3D printed biomimetic rabbit airway simulation model for nasotracheal intubation training. Front Vet Sci 7, 587524. doi: $10.3389 /$ fvets. 2020.587524

Okhovat, S., Milner, T. D., Clement, W. A. et al. (2020). Validation of animal models for simulation training in pediatric laryngotracheal reconstruction. Ann Otol Rhinol Laryngol 129, 46-54. doi:10.1177/0003489419870820

Patronek, G. J. and Rauch, A. (2007). Systematic review of comparative studies examining alternatives to the harmful use of animals in biomedical education. J Am Vet Med Assoc 230, 3743. doi:10.2460/javma.230.1.37

Paul, E. S. and Podberscek, A. L. (2000). Veterinary education and students' attitudes towards animal welfare. Vet Rec 146, 269-272. doi:10.1136/vr.146.10.269

Pawlowski, J. B., Feinstein, D. M. and Gala, S. G. (2018). Dew velopments in the transition from animal use to simulation-based biomedical education. Simul Healthc 13, 420-426. doi:10.1097/sih.0000000000000310

Pereira, G. D., Dieguez, J., Demirbas, Y. S. et al. (2017). Alternatives to animal use in veterinary education: A growing debate. Ankara Universitesi Veteriner Fakultesi Dergisi 64, 235-239. doi:10.1501/Vetfak 0000002804

Pirrone, F., Mariti, C., Gazzano, A. et al. (2019). Attitudes toward animals and their welfare among Italian veterinary students. Vet Sci 6, 19. doi:10.3390/vetsci6010019

Quilici, A. P., Bicudo, A. M., Gianotto-Oliveira, R. et al. (2015). Faculty perceptions of simulation programs in healthcare education. Int J Med Educ 6, 166-171. doi:10.5116/ ijme.5641.0dc7

Quiroga, M. d. M., Clarke, S. and Rajan, R. (2016). Online simulations to support the teaching of physiology. FASEB $J 30$, 553.521. doi:10.1096/fasebj.30.1_supplement.553.21

Rathod, S., Ghoderao, D., Kolte, V. et al. (2019). Simulationbased surgical skill training in internship program. SRM J Res Dent Sci 10, 135-138. doi:10.4103/srmjrds.srmjrds_45_19

Rezende-Filho, F. M., da Fonseca, L. J. S., Nunes-Souza, V. et al. (2014). A student-centered approach for developing active learning: The construction of physical models as a teaching tool in medical physiology. BMC Med Educ 14, 189. doi:10.1186/1472-6920-14-189

Richardson, E. F., Gregory, C. R. and Sucre, E. (1994). Enhancement of the surgical education of fourth year veterinary stu- 
dents by participation in juvenile ovariohysterectomy and castration program. Vet Surg 23, 415. doi:10.1111/j.1532-950X. 1994.tb00500.x

Rosen, M. A., Weaver, S. J., Lazzara, E. H. et al. (2010). Tools for evaluating team performance in simulation-based training. J Emerg Trauma Shock 3, 353-359. doi:10.4103/09742700.70746

Rubeis, G. and Steger, F. (2018). Is live-tissue training ethically justified? An evidence-based ethical analysis. Altern Lab Anim 46, 65-71. doi:10.1177/026119291804600206

Russell, W. M. S. and Burch, R. L. (1959). The Principles of Humane Experimental Technique. London, UK: Methuen.

Salas, E., Rosen, M. A., Held, J. D. et al. (2009). Performance measurement in simulation-based training: A review and best practices. Simul Gaming 40, 328-376. doi:10. 1177/1046878108326734

Self, D. J., Schrader, D. E., Baldwin, J. D. et al. (1991). Study of the influence of veterinary medical education on the moral development of veterinary students. J Am Vet Med Assoc 198, 782-787. https://europepmc.org/article/med/1953847

Šilar, J., Polák, D., Mládek, A. et al. (2019). Development of in-browser simulators for medical education: Introduction of a novel software toolchain. J Med Internet Res 21, e14160. doi: $10.2196 / 14160$

Silverplats, K., Jonsson, A. and Lundberg, L. (2016). A hybrid simulator model for the control of catastrophic external junctional haemorrhage in the military environment. Adv Simul 1, 5. doi:10.1186/s41077-016-0008-Z

Strittmatter, S. (2017). Undervaluation of suffering of experimental animals in Germany. ALTEX 34, 435-438. https://www. altex.org/index.php/altex/article/view/39

Tanya, S. and Dubrowski, A. (2020). Development of a cost-effective pediatric intubation task trainer for rural medical education. Cureus 12, e6604. doi:10.7759/cureus.6604

Taylor, K., Rego, L. and Weber, T. (2018). Recommendations to improve the EU non-technical summaries of animal experiments. ALTEX 35, 193-210. doi:10.14573/altex.1708111

Tolbert, S. (2019). Queering dissection: "I wanted to bury its heart, at least". In C. Taylor, C. Amade-Escote and A. Abbas (eds.), Gender in Learning and Teaching: Feminist Dialogues Across International Boundaries. London, UK: Routledge.

Ulmer, F., Lennertz, J., Greif, R. et al. (2020). Emergency front of neck access in children: A new learning approach in a rabbit model. Br J Anaesth 125, e61-e68. doi:10.1016/j. bja.2019.11.002

Valliyate, M., Robinson, N. G. and Goodman, J. R. (2012). Current concepts in simulation and other alternatives for vet- erinary education: A review. Vet Med (Praha) 57, 325-337. doi:10.17221/6261-vetmed

van Vollenhoven, E., Fletcher, L., Page, P. C. et al. (2017). Heart rate variability in healthy, adult pony mares during transrectal palpation of the reproductive tract by veterinary students. $J$ Equine Vet Sci 58, 68-77. doi:10.1016/j.jevs.2017.08.013

Villanueva, C., Xiong, J. and Rajput, S. (2019). Simulation-based surgical education in cardiothoracic training. ANZ J Surg doi:10.1111/ans.15593

Vogt, L., Duckwitz, V., Arlt, S. P. et al. (2019). Teaching small animal reproduction via virtual patients. Reprod Domest Anim 55, Suppl 2, 81-89. doi:10.1111/rda.13598

Waldau, P. (2007). Veterinary education as leader: Which alternatives? J Vet Med Educ 34, 605-614. doi:10.3138/jvme.34.5.605

Wijewickrema, S., Ma, X., Piromchai, P. et al. (2018). Providing automated real-time technical feedback for virtual reality based surgical training: Is the simpler the better? In C. Penstein Rosé, R. Martínez-Maldonado, H. U. Hoppe et al. (eds.), Artificial Intelligence in Education, Lecture Notes in Computer Science. Cham, Switzerland: Springer International Publishing.

Xiberta, P. and Boada, I. (2019). IVET, an interactive veterinary education tool. J Anim Sci 97, 932-944. doi:10.1093/jas/ sky471

Yankelevitch-Yahav, R., Franko, M., Huly, A. et al. (2015). The forced swim test as a model of depressive-like behavior. $J$ Vis Exp, e52587. doi:10.3791/52587

Yeates, J. W. (2010). Death is a welfare issue. J Agric Environ Ethics 23, 229-241. doi:10.1007/s10806-009-9199-9

Yong, J. A. A., Case, J. B., Kim, S. E. et al. (2019). Survey of instructor and student impressions of a high-fidelity model in canine ovariohysterectomy surgical training. Vet Surg 48, 975984. doi:10.1111/vsu. 13218

Zemanova, M. A. and Knight, A. (2021). The educational efficacy of humane teaching methods: A systematic review of the evidence. Animals 11, 114. doi:10.3390/ani11010114

Zuna, I. and Holt, A. (2017). ADAM, a hands-on patient simulator for teaching principles of drug disposition and compartmental pharmacokinetics. Br J Clin Pharmacol 83, 24262449. doi:10.1111/bcp.13357

\section{Conflict of interest}

The authors declare that they have no conflicts of interest.

\section{Acknowledgement}

We are very grateful to Luísa Bastos for her helpful comments and suggestions during the design and conduct of this study. 